\title{
CONFLICT AVOIDANCE IN INTERNATIONAL LOANS AND MONETARY AGREEMENTS*
}

\author{
Davidson Sommers, $\uparrow$ A. Broches, $\ddagger$ and Georges R. Delaume**
}

\section{INTRODUCTION}

Lenders have good reason to take an interest in avoiding the pitfalls set by the conflict of laws. Characteristically, the lender performs his part of the bargain at the outset, while the performance of the debtor is stretched over a long period; loans with terms of 20 to 25 years are no exception. Future changes in applicable law are, thus, more likely to affect the debtor's performance than the lender's, and history affords lenders ample ground for fearing that in times of economic stress, changes in applicable law will work for the relief of debtors.

When the lender advances funds across national, rather than state, boundaries, his concern with the subject of conflict of laws may be expected to be intensified. Fear of the unknown will give him a special interest in avoiding the application of the foreign law to such matters as negotiability, tender, payment, and usury. But international loans involve additional hazards of a kind not normally encountered in domestic contracts, hazards affecting the medium of payment itself. The risks of exchange restrictions, freezing orders, and currency devaluation haunt international lenders; it is one of their occupational characteristics to be suspicious of the actions of all governments in these fields and, at least in capital-exporting countries, to fear the actions of foreign governments more than those of their own. ${ }^{1}$ There is, thus,

* The views expressed in this article are those of the authors and do not necessarily represent the views of the International Bank for Reconstruction and Development. The authors gratefully acknowledge the assistance and advice received from their colleague, Franz M. Oppenheimer, of the New York and District of Columbia bars, in the preparation of this article.

+A.B. 1926, LL.B. 1930, Harvard University. Member of the New York bar; General Counsel, International Bank for Reconstruction and Development.

¥LL.M. 1936, J.D. 1939, University of Amsterdam, LL.B. I942, Fordham University. Assistant General Counsel, International Bank for Reconstruction and Development. Formerly Legal Adviser, Office of Financial Counselor, Netheriands Embassy, and Netherlands Delegation to Bretton Woods Conferencc. Author, Het oNdeugdeliJke octrool IN DE INBreukprocedure (1939), and Law, in The Contribution of Holland to the Sciences (1943).

* LL.B. 1942, Docteur en Droit 1946, University of Paris. Attorney, International Bank for Reconstruction and Development. Formerly Legal Counselor, International Monetary Fund; Chargé de Cours des Facultés de Droit, France. Author, Les Conflits de lors à la Veille du COde Civil (I947); Les Conflits de lois à la Veille du Code Civil dans les Traités Diplomatiques (i948); AmericanFrench Private International Law (Columbia University Bilateral Studies in Private International Law No. 2, 1953); and articles on the conflict of laws and comparative law published in American, Canadian, and European law reviews.

${ }^{1}$ This attitude might, on occasion, prove to be a treacherous guide. The classic conflict problems under international loans arose out of gold clauses. A stipulation of American law by an American forcign lender in the twenties would have helped foreign courts to hold applicable the American Joint Resolution of June 5, 1933, 48 STAT. IY2, 31 U. S. C. $\$ 463$ (1952), which invalidated gold clauses, and would, thus, have contributed to the frustration of the lender's objectives. See also notes 7 and 23 , infra. 
reason to expect that international lenders will not only insist on including stipulations of the applicable law in their contracts, but also on making their own law applicable in preference to other laws.

This article will examine whether this expectation is justified. It will describe the practice of leading markets in regard to stipulations of applicable law in international loans; monetary agreements will be mentioned in passing. It is hoped that this survey will contribute to an understanding of the variety of considerations which international lenders and their counsel have to take into account in dealing with problems of avoiding the conflict of laws.

Descriptions of practice must be put in general terms, and this description does not purport to be complete in scope or detail. What has been attempted is the delineation of trends, to which there are doubtless many exceptions. Little descriptive literature has been found, and the authors have had to rely on their own experience, on examination of such loan agreements and prospectuses as they have been able to find, and upon information supplied by a number of eminent lawyers and financiers who have been good enough to give the authors the benefit of their own first-hand experience. ${ }^{2}$

At the outset, it should be mentioned that the effectiveness of stipulations of applicable law is subject to important limitations, and an awareness of these is necessary for an understanding of current practices. ${ }^{3}$ The most important of these limitations is the doctrine that a stipulation of applicable law will not be given effect if the law chosen is found to be inconsistent with the public policy of the forum. This well-known doctrine drastically limits freedom of action and has often prevented enforcement of contracts in accordance with their terms. Another significant limiting factor is of a practical rather than of a juridical nature. A choice by express stipulation of the law of a particular country may turn out to be futile as a practical matter if the contract cannot be enforced in that country. The field of international loans offers many examples of cases where such enforcement is impossible either because the debtor is immune by law (e.g., in loans to foreign governments) or because the debtor cannot be reached by process in the jurisdiction or has no assets which can be reached.

One further preliminary point should be mentioned. There is no likelihood of

I Information has been supplied particularly from the United States, the United Kingdom, Canada, France, Switzerland, and the Netherlands. For reasons of professional confidence, it has not been possible in every case to cite documentary materials by name.

${ }^{3}$ Such interesting questions as whether there are legal obstacles to stipulating the law of a country which has no contact with the transaction involved or to stipulating against future changes of the proper law (see, e.g., Herbert F. Goodrich, Conflict of Laws 326 et seq. (3d ed. 1949); F. A. Mann, The Legat Aspect of Money 266 (2d ed. 1953); and Delaume, L'Autonomie de la Volonté en Droit linternational Privé, in 39 Revue Critioue de Droit International Privé [hereinafter Rev.] 321, 336-37 (France I950)) appear to have little practical application in the field of international loans and monetary agreements. For an attempt to deal with future changes of law, see the provision found in art. VII, $\$$ IX of the Indenture of Oct. I, I925, between Rudolf Karstadt, A. G., a German company, and Amcrican bankers reading in part as follows: ". . . the company ... hereby agrees to waive ... the benefit and advantage of any valuation, stay, appraisement and extension law or laws now existing, or which may hereafter be passed either in Germany or in the United States of America. . . ." 
any conflict of laws in respect of the capacity or authority of a governmental or corporate borrower to contract a debt or to issue securities. It is generally recognized that these matters are governed by the borrower's personal law-that is, by the law of the borrower itself, if it is a government, or by the law of the corporate domicile of the borrower. ${ }^{4}$ There is, therefore, no real problem of avoiding conflicts of law on these matters, and international loans normally deal with them, if at all, not by formal stipulation, but by mere reference to the particular statute or other source of authority under which the borrower purports to act. ${ }^{5}$

There remains for discussion the problem of avoiding conflicts with respect to the validity, ${ }^{6}$ interpretation, and performance of the loan contracts. These are the points on which lenders are apprehensive about the future and on which they try to protect themselves by stipulations of applicable law. Since the risks of conflicts, and the means available for meeting them, differ as between types of lenders and types of borrowers, a description of the practice can best proceed on the basis of a classification of international loans into four main categories, depending on the character, private or public, of lender and borrower, as follows:

a. loans by private lenders to private borrowers;

b. loans by private lenders to foreign governments and to international organizations;

c. loans by public lenders to private borrowers; and

d. loans by public lenders to foreign governments and to international organizations. ${ }^{7}$

'In Goodman v. Deutsch-Atlantische T. Gesellschaft, I66 Misc. 509, 2 N. Y. S. 2d 80 (Sup. Ct. r938), a deed of trust on properties of a German cable company securing bonds and coupons sold in New York provided that the obligations undertaken by the borrower were "covered" by German law, although the relations between the parties were generally "governed" by the law of New York. It was held that the reference to German law was limited to such matters as corporate action and authority to enter into the deed of trust and that all other matters were governed by the law of New York. On this problem generally, see Rieport of THE CoMmttee for tHe Study of INTERNational LoANs [hereinafter L. N. Report] (League of Nations Pub. No. C I45, M 93, I939, II.A, \$73).

"Sce, e.g., the following prospectuses concerning bonds issued in the United States: French Mail Steamship Lines $7 \%$ External Sinking Fund Gold Bonds of 1924 ; City of Milan $61 / 2 \%$ External Sinking Fund Bonds of x927; City of Oslo $4 \frac{1}{2} \%$ External Sinking Fund Bonds of 1936 . With respect to bonds issued in the Netherlands and Switzerland, see the prospectus for the Emprunt Extérieur de la Ville de Paris $5 \%$ of 1932 . It is also frequently stipulated in trust indentures, underwriting agreements, and direct loan contracts that the borrower represents that it has taken all the corporate or legislative action required to make its obligations valid and binding upon it.

"What is referred to here is the "essential validity" of the contract, as that term is often used, as opposed to the formalities of execution and issue.

This classification, which has been purposely oversimplified for convenience of discussion, omits loans to political subdivisions, government-owned corporations, and autonomous public institutions, bodies, and authorities. These entities differ strikingly in legal status. On the one extreme are territorial governments enjoying a large measure of independence. On the other are entities which, although government-owned, have essentially the legal status of private corporations. Between these two extremes, there is a whole range of institutions possessing governmental attributes in greater or lesser degree. In many instances, their status is not entirely clear under their own law; and foreign jurisdictions will not necessarily adopt the domestic view. An examination of these questions would go beyond the scope of this article. In any event, we believe that the oversimplified classification which we have adopted permits an adequate discussion of the practice. 
II

\section{Loans by Private Lenders to Private Borrowers}

The normal transaction in this category is one in which there would be no difficulty in deciding the applicable law by usual and generally recognized principles of the conflict of laws. Whether the transaction takes the form of a loan agreement or a bond issue, the arrangements are usually such as to make the law of the lender's country applicable. The lender's country is usually the place where documents are signed and delivered, where funds are received by the borrower and are to be repaid. The language of that country is usually used, and its fashions in draftsmanship observed. Where a trustee or a bondholders' agent is appointed, it will normally be a national and resident of the lender's country, and the same is true of fiscal agents, paying agents, and registrars. The regulatory requirements of the lender's country, such as registration and listing, will have been complied with. Thus, there is usually every reason to assume that the law of that country will be recognized as governing questions of validity, interpretation, and performance. ${ }^{8}$

It is, therefore, interesting that lenders in the principal financial markets consistently include stipulations of applicable law in their loan agreements with private foreign borrowers and in bonds issued in those markets by private foreign issuers; and that the law designated by stipulation is usually the law of the lender's country or state, ${ }^{9}$ which would presumably be applicable even in the absence of a

${ }^{8}$ The following cases, for example, relied on all or most of these factors in holding the law of the lender applicable: Guaranty Trust Co. of New York v. Henwood, 307 U. S. 247 (r939); Bethlehem Steel Co. v. Zurich Central Accident and Liability Insurance Co., and Bethlehem Stecl Co. v. AngloContinentale Treuhand A. G., 307 U. S. 265 (I939); Hartman v. United States, 65 F. Supp. 397 (Ct. Cl. 1946); Compania de Inversiones Internacionales v. Industrial Mortgage Bank of Finland, 269 N. X. 24, I98 N. E. 617 (r935); Trésor Public et Soc. Royal Bank of Canada v. Schumann, Court of Appeal of Paris, May 16, I95r, [1952] Juris-Classeur Periodique [also called La Semaine Juridique, hercinafter J. C. P.] II. 6887 ; Aachener Kreissparkasse v. Giroverband, Supreme Court of Germany, May 28, 1936, 63 Journal Du Droit Internatjonal [hereinafter Clunet] 951 (France 1936); Minerva Ins. Co. v. The Norwegian Government, Supreme Court of Norway, Dec. 8, 1937, 38 BulLETIN dE L'INsTrTut JunidiQue International. [hereinafter B. I. J. I.] 7 I (France 1938); Skandia v. National Debt Office, Supreme Court of Sweden, Jan. 30, 1937, 36 B. I. J. I. 327 (France 1937); Amsterdam Stock Exchange Committec v. Ministry of Finance (as translated in German), Supreme Court of Denmark, Jan. 30, I939, I3 ZEITschrift fuer Auslaendisches und Internationales Privatrecht 825 (Germany 1942); Rotterdam Gold Bonds Case, Supreme Court of the Netherlands, Feb. II, 1938, Ann. Dic. Pub. Inr'L L. Cases [hereinafter ANN. Dig.] 1919-42, 26 (I947); Rex v. International Trustee for the Protection of Bondholders A. G., [1937] A. C. 500; British and French Trust Corp. v. New Brunswick Ry. Co., [1937] 4 All E. R. 516, aff'd on other grounds, [x939] A. C. 1. But see Mount Albert Borough Council v. Australasian Temperance and General Mutual Life Assurance Co., [1938] A. C. 224. See also, Vienna Loan of 1902 Case, German Supreme Court, Nov. 14, 1929, 126 Entscheidungen des Reichsgerichts in Zivilsachen [hereinafter R. G. Z.] 196.

'Where the loan is secured by a mortgage or similar charge on property located outside the lender's country, it is usual to provide, for obvious reasons, that the security arrangement is to be governed by the law of the situs of the property. See, for example, the following provision ( $\$ 20.07)$ of an Indenture, dated Feb. 2, I950, between Mexican Light and Power Co., Ltd., a Canadian corporation, and National Trust Co., Ltd., of Toronto, as Trustee, which provides as follows:

"This Indenture and the Bonds and coupons shall be construed in accordance with the laws of the Province of Ontario, Canada, and the laws of Canada applicable therein, and shall be treated in all respects as Ontario contracts, save in respect of the security created or to be created hereby or pursuant hereto upon the immovable properties of the Company and its subsidiaries in 
stipulation. Bankers and their legal advisers seem to believe that a contractual choice of law can add something to the protection afforded by the rules of the conflict of laws, even in this relatively well-explored area. The authorities indicate that effect will normally be given to such stipulation ${ }^{10}$ subject, of course, to considerations of public policy.11

Only one of the leading financial markets, France, does not appear to follow the general practice in this regard. That exception can probably be explained by the unique French doctrine of "international transactions," under which effect is given to the intention of the parties, as expressed in monetary clauses in international transactions, without regard to the principles of the conflict of laws normally applied by French courts in other types of cases. ${ }^{12}$

the United Mexican States and the receipt of income therefrom, which shall be governed by the laws of that country."

Another interesting provision (art. XX) is found in the Form of Obligation issued by the Liquidation of United Steel Works Corp. (Vereinigte Stahlwerke Aktiengesellschaft) pursuant to a Declaration and an Agreement of Deposit, dated Jan. I, r953:

"Except as herein otherwise provided, this Obligation and the rights of the Obligees hereunder shall for all purposes be governed by the laws of the State of New York, United States of America, and shall be construed and enforced in accordance with such laws; provided, that this provision is without prejudice to any mandatory provision of German law applicable either (a) to the creation of mortgages or the foreclosure thereof or other proceedings relative to real estate or fixed property or (b) to any proceedings which may be brought or instituted by the Obligees or either of them in Germany for the enforcement of this Obligation or any one or more of the provisions, covenants or agreements herein contained."

Cf. the following provision of a trust deed between an Austrian corporation and an English company which provides, in part, as follows:

"This Deed and the Bonds shall be construed and have effect as instruments made in England and in accordance with the Laws of England and the [Borrower] hereby submits to the jurisdiction of the High Court of Justice in England as regards all matters and questions arising hereunder or under the Bonds. ... Provided always that nothing in this clause contained shall hinder or prevent the Trustees from taking proceedings in the Courts of Austria or other countries where the mortgaged premises are situated and from exercising all rights and powers under the Laws for the time being in force in Austria or other countries where the mortgaged premises are situated which they would have been entitled to take or exercise if this clause had not been inserted."

For a rarer exception to the statement in the text, but one which is, nevertheless, useful as illustrating the dangers of generalization in this field, see $\$ x_{4}$ of the terms and conditions of the bonds in the Prospectus for the 1954 loan issued in Switzerland by International Standard Electric Corp., a New York corporation, where the New York law (the borrower's law) was designated as applicable. Another exception is found in the recent English case, In re Helbert Wagg, [1956] 22I L. T. 24, in which the German law of the borrower rather than the English law of the lender was stipulated to be applicable.

${ }^{10}$ See, e.g., Société Antwerpia v. Ville d'Anvers, Supreme Court of Belgium, Feb. 24, r938, Rev. 66r (1938), 66 Clunet 413 (France 1939); Ver. voor den Effectenhandel v. Bataafsche Petroleum Mij., Supreme Court of the Netherlands, March 13, I936, Nederlandsche Jurisprudentie No. 281 (1936), 3I REv. 733 (France 1936), 36 B. I. J. I. 315 (France I936); Amsterdam Stock Exchange Committee v. Government of Finland, Helsingfors City Court, Dec. 23 , 1937, 38 B. I. J. I. 280 (France 1938); RheinischWestfaelische Elektrizitaetswerk A.G. v. Anglo-Continentale Treuhand, Swiss Federal Tribunal, July 7. 1942, [1942] Recueil Officiel [hereinafter R. O.] 68. II. 203, 73-76 CzUNET 208 (France 1946-49).

${ }^{11}$ See Bethlehem Steel Co. v. Zurich General Accident and Liability Ins. Co., 307 U. S. 265 (1939). In several cases, public policy has been invoked to deny enforcement of foreign laws abrogating gold clauses. Sec, e.g., Aachener Kreissparkasse v. Giroverband, Supreme Court of Germany, May 28, I936, 63 Clunet 95I (France 1936); Royal Dutch Loan, Supreme Court of the Netherlands, May 13, 1936, 36 B. I. J. I. 304 (France 1936); and Messageries Maritimes Debentures Case Supreme Court of the Netherlands, April 28, 1939, ANn. Dig. 1919-42, 28 (1947).

${ }^{12}$ See, e.g., Etat Français v. Comité de la Bourse d' Amsterdam, Cour de cassation (Ch. civ., sect. civ.), Jan. 21, I950, [195I] Sircy Jurisprudence r.I, 39 REv. 609 (France 1950), [195I] Dalloz Juris- 
Even where the practice is to stipulate the applicable law, there is diversity in the forms of stipulation actually employed. Despite this diversity, most clauses found in loan agreements and bond issues are precisely drafted and indicate clearly the matters which the parties intend shall be governed by the designated law. A typical American example is as follows: $:^{13}$

This Indenture, the Guarantee Agreement, the Debentures issued hereunder and the coupons appertaining thereto and the guarantee endorsed thereon, and all rights arising under any of the same shall be construed and determined in accordance with the laws of [e.g., New York], and the performance of each thereof shall be governed and enforced according to such law.

Comparable clauses can be found in loans negotiated in other markets. For example, the following provision is found in bonds issued in the Netherlands: ${ }^{14}$

This Agreement and all rights and obligations arising thereunder shall be governed by Dutch law. (as translated)

and this in bonds issued in Switzerland: ${ }^{15}$

The loan contract provides that all the rights and obligations of the parties thereto shall, in all respects, be governed by Swiss law. (as translated)

and this in a British trust deed: ${ }^{16}$

The meaning and construction of this Deed and the rights and duties of the parties hereunder shall be determined in accordance with English law.

Not all forms of stipulation are so specific. A common type of clause provides that the loan agreement or the bonds "shall be deemed to be a contract made under the laws of [e.g., the State of New York] and for all purposes, shall be construed in accordance with the laws of [said State],"17 or "shall be construed and determined

prudence 749. On this doctrine, see, e.g., among recent publications, ARTHur NussbuUm, Monex iN t7iE Law 267 et seq. (2d ed. I950); Henri Batiffol, Traite Elementaire de Droit Intrernationar Pruvt 675 (2d ed. 1955); Delaume, stlpra note 3, at 335-37; Lerebours-Pigconnière, $A$ Propos du Contrat International, 78 Crunet 4 (France 195I).

${ }^{13}$ Bataafsche Petroleum Company Loan $4 \% \frac{1}{2} \%$ of 1927 (this provision was given effect by the Supreme Court of the Netherlands in the case of Ver. voor den Effectenhandel v. Bataafsche Petrolcum Mij., stpra note ro). See also Rudolph Karstadt A. G., First Mortage $7 \%$ Sinking Fund Gold Bonds, I925 (Indenture, art. XIII, $\$ I_{4}$, incorporated by reference into the bonds); Rheinelbe Union twenty-ycar $7 \%$ Sinking Fund Mortgage Gold Bonds, 1926; and Banco Nacional (Panama), Guarantecd Sinking Fund $6 \frac{1 \%}{2} \%$ Twenty-year Gold Bonds, Series A 1926 (Indenture, art. XI, \$7, incorporated by reference into the bonds).

${ }^{14}$ Naphtachimie, S. A. Paris, $4 \frac{1 / 4}{\%}$ loan of I955. See also Compagnie Internationale des WagonsLits 4\% loan of 1955; and Anglo-American Rhodesian Development Co., Ltd., 41/2\% loan of 1955 .

${ }^{15}$ West Rand Investment Trust, Ltd., Johannesburg, $4 \% \frac{1}{2} \%$ loan of r 954 . Sec also Compagnie Financière Belge des Pétroles External Loan $4 \%$ of 1954 ; and Istituto Mobiliare Italiano External Loan $4 \frac{1}{2} \%$ of 1955 .

${ }^{10}$ Trust Deed between a South African company and an English company.

${ }^{17}$ See, e.g., Trust Indenture, dated October $x$, 1948, between the Rio de Janeiro Tramway, Light and Power Co., Ltd., and National Trust Co., Ltd. (art. XIV, \$14.05, Law of the Province of Ontario); Indenture between Aluminium Co. of Canada, Ltd., and Aluminium, Ltd., on the one part, and, on the other, Montreal Trust Co. and Hanover Bank, dated May I, 1952 (art. XIII, \$13.04, Law of New York). 
in accordance with the laws of [e.g., the State of New York]."18 Presumably, these provisions are intended to cover both matters of validity and of construction. They may be intended to cover matters of performance as well, but it cannot be said that they would inevitably be so understood.

The case of British and French Trust Corp. v. New Brunswick Ry Co., ${ }^{19}$ though not involving a stipulation of law, gives grounds for being cautious on the point. This was a suit by a bondholder in an English court to enforce a gold value clause contained in sterling bonds issued by a Canadian corporation and payable either in England or Canada at the option of the holder. The House of Lords recognized Canadian law to be the "proper law" of the contract but, nevertheless, held that English law, and not Canadian law, applied to the part of the performance that was to be rendered in England and enforced the gold clause notwithstanding a Canadian statutory abrogation of gold clauses.

The fact that stipulations of law may sometimes, because of express limitations of scope or ambiguous language, be inadequate to avoid all conflict-of-laws issues does not necessarily mean that the limitation or ambiguity reflects either the preference of the lender or a lack of skill on the part of the draftsman. Although bankers and their legal advisers generally prefer to include precise stipulations of applicable law in their loan documents, they will not always insist on them in the face of determined resistance by borrowers. The limited or ambiguous provisions that are sometimes found may be explainable as drafting compromises of the kind with which all lawyers are familiar.

\section{Exchange Contracts between Private Parties}

The term "monetary agreements" is generally understood to refer to payments agreements, clearing agreements, and similar types of agreement normally entered into between governments. They need not, therefore, be discussed in the category of private lending. However, the term may also be used to cover exchange contracts, particularly arrangements for the present or future sale of one currency against another, which frequently are entered into by private parties. Since exchange contracts and their enforcement have received special treatment in an international agreement, the Articles of Agreement of the International Monetary Fund, some mention must be made of them in relation to the problem of avoiding conflicts of law in the monetary field.

Article VIII, section 2(b), of the Articles of Agreement of the International Monetary Fund provides as follows:

${ }^{18}$ Loan Agreement of February 8, I945, between The Chase National Bank of the City of New York and the Kingdom of the Netherlands, $\$ 9$, para. 9.2. Cf. an even more limited provision in an Indenture, dated March I, 1926, relating to the Roman Catholic Church in Bavaria, 25 year Sinking Fund Gold Bonds, Ser. A, art. X, $\S 3$ : "This indenture is written in the English language and shall be executed and delivered in the City of New York, State of New York, United States of America."

${ }^{10}$ [1937] 4 All E. R. 516, aff'd on other grounds, [1939] A. C. I. For a critical appraisal of this and related cases, see $\mathrm{MANN}_{\mathrm{AN}}$ op. cit. sutpra note 3 , at 264 ; and Nussbaum, op. cit. supra note 12 , at 420 et seq. 
Exchange contracts which involve the currency of any member and which are contrary to the exchange control regulations of that member maintained or imposed consistently with this Agreement shall be unenforceable in the territories of any member.

This remarkable provision has been officially interpreted by the Executive Directors of the Fund in a decision which states in part as follows: ${ }^{20}$

An obvious result of the foregoing undertaking is that if a party to an exchange contract of the kind referred to in Article VIII, Section 2(b) seeks to enforce such a contract, the tribunal of the member country before which the proceedings are brought will not, on the ground that they are contrary to the public policy (ordre public) of the forum, refuse recognition of the exchange control regulations of the other members which are maintained or imposed consistently with the Fund Agreement.

A discussion of the scope and effect of this provision of the Fund Agreement would carry us beyond the bounds of this article. ${ }^{21}$ It is sufficient to note that the provision is, in effect, a stipulation by international agreement that the public policy of the forum shall not override the applicable municipal law, whatever it may be, in a proceeding to enforce an exchange contract. Whatever its scope and effect, it represents an unusual method of avoiding conflicts of law.

\section{III}

\section{Loans by Private Lenders to Foreign Governments and}

\section{INTERNATIONAL ORGANIZATIONS}

The view has sometimes been advanced that loans by private lenders to foreign governments, as distinguished from loans to private borrowers, are outside the scope of the conflict of laws. It has been suggested that, because of the disparity of status between the parties, such loans should be governed by public international law rather than municipal law. ${ }^{22}$ This view has, however, received little support from the courts. Decisions of national tribunals ${ }^{23}$ and international tribunals ${ }^{24}$ support the application of municipal rather than public international law in this field.

${ }^{20}$ Fund Circular No. 8 (March 15, 1950).

${ }^{21}$ See, e.g., Nussbaum, op. cit. supra note 12 , at 525 et seq.; ManN, op. cit. supra note 3 , at 378 et seq.; Meyer, Recognition of Exchange Controls after the International Monetary Fund Agrecment, 62 Yale L. J. 867 (1953); Gold, The Fund Agreement in the Courts (I), I IMF Stafp Papens 315 (r95I), (II), 2 id. at 482 (I952), (III), 3 id. at 290 (1953), The Interpretation by the International Monetary Futnd of Its Articles of Agreement, 3 INT'L \& CoMP. L. Q. 256 (1954), Article VIII, Section 2(b) of the Fund Agreement and the Unenforceability of Certain Exchange Contracts: $A$ Note, 4 IMF STAFF Papers 330 (1955); Delaume, De l'Elimination des Confits de Lois en Matière Monétaire Réalisée par les Statuts du Fonds Monétaire International et de ses Limites, 81 CuUNET 332 (France 1954) (with an English translation by the editor); Lachman, The Articles of Agreement of the International Monetary Fund and the Unenforceability of Certain Exchange Contracts, in NeDERLANDs TiJdschrupt voon InTERnationaAi. Recht 148 (1955); Aufricht, Das Abkommen des Internationalen Waehrungsfonds und die Unerzwingbarkeit bestimmter Vertraege, in ZeItschrift fUER OEFFentzICHEs Recht 529 (Ocsterr ed. 1955).

${ }_{22}^{2}$ For references, see I E. Borchard, State Insolvency and Foreign Bondholders 4 et seq., 64 et seq. (195I). See also Schmitthoff, The International Government Loan, 19 J. Comp. LEg. \& INT'L L. (3d ser.) 179 (I937).

${ }^{23}$ See, e.g., Legal Opinion given by the Supreme Court of Austria, Nov. 26, 1935, in the case of the Austrian Government Loans (League of Nations Loans) of I923 and 1930, 31 REv. 7I7 (France 1936), 
The Permanent Court of International Justice, in the Serbian and Brazilian Loan cases, ${ }^{25}$ seems to assume that a special rule of the conflict of laws should be applied in respect of private loans to foreign governments. In these two cases, the debtor governments had issued bonds in France, payable in term of gold francs. The governments contended that French law had been intended to apply, and that under French law, gold clauses had become unenforceable. Consequently, the governments argued that they could discharge their obligations by paying depreciated francs without regard to the gold clause in the bonds. The court rejected this argument in both cases on the ground that, in the absence of express provision to the contrary, it is to be presumed that a sovereign state intends to contract under its own law. Since there was no such express statement, the court held the laws of Serbia and Brazil applicable and both governments bound by the gold clauses in the bonds. ${ }^{26}$

Most national tribunals have refused to follow the Serbian and Brazilian Loans cases. In a number of cases arising during the thirties, laws other than those of borrowing governments, and particularly laws of places of issue, have been held applicable by national courts on the basis of the same considerations that would be given weight in cases of loans to private borrowers. For example, in the leading British case, Rex v. International Trustee for the Protection of Bondholders A.G., the House of Lords held that dollar bonds issued in New York by the British Government were subject to the American Joint Resolution of June 5, I933, and that the gold clause in the bonds was, therefore, unenforceable. ${ }^{27}$

Nevertheless, a decision by the Permanent Court of International Justice is not to be disregarded, and a presumption of the kind suggested in the Serbian and

and judgment of the same court in the same case, July 10, 1936, 64 Clunet 333 (France I937); Amsterdam Stock Exchange Committee v. Ministry of Finance (as translated in German), Supreme Court of Denmark, Jan. 30, 1939, 13 Zeitschrift fuer Auslaendisches und Internationales PrivatRECHT 825 (Germany r942); Amsterdam Stock Exchange Committee v. Government of Finland, Helsingfors City Court, Dec. 30, 1937, 38 B. I. J. I. 280 (France 1938); Minerva Ins. Co. v. Norwegian Government, Supreme Court of Norway, Dec. 8, I937, 38 B. I. J. I. 7I (France I938); Skandia v. Na. tional Debt Office, Supreme Court of Sweden, Jan. 30, I937, 36 B. I. J. I. 327 (France r937); Rex v. International Trustee for the Protection of Bondholders, A. G., [1937] A. C. 500. A French case, decided on jurisdictional grounds only, seems to adopt the same view, Trésor Français v. Hébert, Court of Appeal of Paris, July 20, 1938, 66 Cluner I04 (France 1939), a view consistent with that prevailing in respect to governmental transactions other than loans. Carathéodory v. Etat Français, French Supreme Court, May 31, 1932, 60 Clunet 347 (France I933).

at Serbian and Brazilian Loans Cases, P. C. I. J., Ser. A, Nos. 21 and 22 (I929); Tilley v. BengelloumMaspero, Mixed Tribunal of Tangiers (App. Div.), May 18, I935, 3 I Rev. I3I (France I936).

${ }^{35}$ Stupra note 24 .

${ }^{20}$ The Court said, Ser. A. No. 20, at 42, No. 21, at I2I: "A sovereign state . . cannot be pre. sumed to have made the substance of its debt and the validity of the obligations accepted by it in respect thereof, subject to any law other than its own." This view also prevailed in certain cases decided by domestic courts. However, it is significant that, in each of these cases, there were other factors supporting the application of the law of the debtor government which, in fact, coincided either with the lex loci coniractus, Hartmann v. United States, $65 \mathrm{~F}$. Supp. 397 (Ct. Cl. 1946), or the lex loci solutionis, ibid., or the monetary system presumptively intended by the parties, Bonython $v$. The Commonwealth of Australia, [195X] A. C. 20I, or the law governing the principal contract guaranteed by the debtor government. Trésor Public et Soc. Royal Bank of Canada v. Schumann, Court of Appeal of Paris, May 16, 1951, [1952] J. C. P. II. 6887.

27 [r937] A. C. 500. See also cases cited in note 26 supra. 
Brazilian Loans cases would certainly cause international lenders to be apprehensive. One might, therefore, expect that in lending to foreign governments, bankers would be particularly desirous of establishing their own law as the law governing the contract. And, in fact, current practice in drafting loan agreements with foreign governments, under loans not involving public issues of bonds, seems to be in accordance with that expectation. Loan contracts of that type between bankers and foreign governments consistently include provisions stipulating that the law of the lender's country shall govern. ${ }^{28}$

Surprisingly enough, however, the practice in bond issues seems to be quite different. Recent issues by foreign governments in the markets of the United States, Canada, the Netherlands, and the United Kingdom contain no stipulations of applicable law. ${ }^{29}$ The same is true, except in the Netherlands, of the bond issues floated in those markets by the International Bank for Reconstruction and Development. $^{30}$

The omission of such stipulations is probably not due to any intention on the part of bankers and their legal advisers to distinguish between privately placed loans, on the one hand, and publicly offered bond issues, on the other. A more plausible explanation can perhaps be found in governmental reluctance, presumably based on considerations of prestige rather than of substance, to agree to submit to the laws of another government-a reluctance which may well be stronger in regard to documents that are to be widely published, as in a bond issue, than in regard to those which are to be seen only by a few lending institutions.

So far as the motivations of the lenders are concerned, there is reason to believe that they are governed by two principal considerations in acceding to the desires of governments. In the first place, lenders appear to believe that, notwithstanding the suggestion of the Permanent Court of International Justice, the law of the place of issue will be held applicable because so many of the circumstances of the issue (place of issue, place of payment, medium of payment, nationality and residence of fiscal agents, paying agents and registrars, compliance with local regulatory requirements, etc.) call for the application of that law. Of more importance, probably, is the circumstance that in most of these cases, invocation by the borrowing

${ }^{28}$ See, e.g., Loan Agreement, dated Oct. 31, 1949, between The Chase National Bank of the City of New York and the Republic of France, $\S$ 1o, para. 10.3; similar stipulations are also, according to the writers' information, found in loans negotiated in other financial centers. For an carlier cxample, see, Loan Contract between the Republic of Nicaragua and Brown Brothers \& Co., etc., dated Oct. 8, 1913, art. XV, reprinted in Robert W. Dunn, American Foreign Investments 378 (1926).

${ }^{29}$ For example, no conflict-of-laws provision is found in bonds issued in New York by the Kingdom of the Netherlands, the Italian Republic, and the Kingdom of Norway in 1947, the State of Isracl in 1950, the Kingdom of Belgium in 1954, and the Union of South Africa in 1955; or in bonds issued in Canada by the Commonwealth of Australia in 1955; or in bonds issued in the Netherlands by the Union of South Africa and the Kingdom of Belgium in 1955; or in bonds issued in England by the Commonwealth of Australia in I948-1949.

${ }^{30} \mathrm{See}$, e.g., the following IBRD bond issues: in the United States, $3 \frac{1}{2} \%$ Ten Year Bonds of 1955; in the United Kingdom, 31/2\% Twenty Year Stock of 1954 ; and in Canada, $31 / 4 \%$ Ten Year Bonds of 1955. See, however, for the Netherlands, $3 \frac{1 / 2}{\%}$ Twenty Year Bonds of 1955 . 
government of the doctrine of sovereign immunity would prevent any enforcement in the courts of the lender's country. Lenders, for the most part, do not regard a right to sue in the courts of the borrowing country as a satisfactory remedy. In some countries, and particularly in the United States, they, therefore, tend to feel that the conflict-of-laws problem is overshadowed by the problem of sovereign immunity, which would make any stipulation of applicable law ineffective for practical purposes.

The same reasons presumably explain why, in the cases where stipulations of the lender's law have been included in loans to governments, the form of stipulation employed is sometimes limited in scope or ambiguous. For instance, the provision may consist of nothing more than that the contract or the bonds shall be "construed" in accordance with the law of the place of making or the place of issue, ${ }^{31}$ or that "the English text shall prevail."32

The practice of the Swiss market is exceptional and may shed some light on the considerations underlying the practice in other markets. Bond issues by foreign governments in the Swiss market generally include a stipulation that the Swiss law shall govern. This stipulation, however, is accompanied by a provision for acceptance of process in Switzerland and submission to Swiss courts. ${ }^{33}$ Under Swiss law, such a waiver of immunity by a foreign government is considered irrevocable and enforceable, ${ }^{34}$ and the stipulation of Swiss law, thus, rests on a solid legal foundation and has obvious practical significance.

Some European countries, like France, ${ }^{35}$ have adopted the same view on govern-

"See, e.g., in the case of loans, Loan Contract between the Republic of El Salvador and Minor C. Keith, dated June 24, 1922, art. XXIII (h), reprinted in DuNN, op. cit. supra note 28, at 247: "This Contract shall be construed in accordance with the laws of the State of New York, United States of America." See also, in the case of bond issues, Argentine Republic Sinking Fund External Conversion Loan $4 \%$ Bonds of 1937 , due in 1972 , containing the same clause as in the loan just cited. There is no doubt that similar examples could be found in loans to private foreign borrowers.

${ }^{33}$ See, e.g., German External Loan 1924 (The Dawes Loan); The German International 51/2\% Loan (The Young Loan). As to the construction of the latter loan documents and the slight weight attached to the quoted provision by the Swiss Federal Tribunal, see Aktiebolaget Obligationsinteressenter v. The Bank for International Settlements, Swiss Federal Tribunal, May 26, 1936, [1936] R. O. 62 II. I40. See also the Austrian Government Guaranteed Loan I923-1943; the Austrian Government International Loan 1930; The Loan Contract between the Republic of El Salvador and Minor C. Keith, dated June 24, 1922, art. XXIII (g), reprinted in DunN, op. cit. supra note 28, at 247 ; "This contract shall be drawn up in the English and Spanish languages, but, in the interpretation of the same, the English text shall govern." The Indenture, dated March $\mathrm{I}, \mathrm{3926}$, of the Roman Catholic Church in Bavaria, supra note I8, art. $\mathrm{X}, \S \mathrm{I}$, contains a similar provision giving preference to the English over the German text of the Indenture.

${ }^{33}$ See, e.g., Belgian Congo Guaranteed Loan 4\% I953 (Congo Belge Emprunt Garanti 4\% 1953), Kingdom of Belgium External Loan $4 \%$ I952 (Emprunt Extérieur du Royaume de Belgique $4 \%$ I952), and Union of South Africa Loan $4 \%$ I952 (Emprunt de l'Union sud-Africaine $4 \%$ x952). See also IBRD $3 \frac{1}{2} \%$ Twenty Year Bonds of 1955 .

"K.k. Oesterreichisches Finanzministerium v. Dreyfus, Swiss Federal Tribunal, March 13, x918, [I9I8] R. O. 44 I. 49; Etat Yougoslave v. S. A. Sogerfin, Swiss Federal Tribunal, Oct. 7, 1938, [1939] J. C. P. II. 327 (I939). See also r P. Guggenheim, Tratté de Droit International Public i84 (I953).

${ }^{35}$ See, e.g., Rochaid-Dahdah v. Gouvernement Tunisien, Tribunal Civil Seine, April 10, 1888, 15 Clunet 670 (France 1888); Ben Aiad v. Bey de Tunis, Tribunal Civil Seine, June 30, r89r, I9 Clunet 952 (France $\times 892$ ). Both cases involved waivers of immunity in direct loan contracts between French bankers and the Tunisian Government. The same solution would presumably obtain in the case of governmental bonds, although no case has been found. 
mental waivers of immunity. But in the United States, it is far from clear that such a waiver would be held irrevocable; $;^{36}$ and in England, it appears to be settled that the waiver may be revoked by a foreign sovereign pleading immunity at the time of suit. ${ }^{37}$

Even where under prevailing practice bond issues contain no stipulation of applicable law, attempts are often made to protect by substantive provisions against particularly important risks that may arise under the law of the borrowing government. For example, it is quite common, in governmental as well as in private issues, to include covenants that payments shall be made free of taxes imposed by the laws of the borrower's country. ${ }^{38}$ And in Switzerland where lenders are generally resentful of exchange controls and proof-of-ownership requirements, they often insist on elaborate covenants on these points. ${ }^{39}$

${ }^{36}$ See, e.g., De Simone v. Transportes Maritimos de Estado, 199 App. Div. 602, 191 N. Y. S. 864 , 867 (Ist Dep't 1922) (dictum), aff'd on rehearing, 200 App. Div. 82, 192 N. Y. S. 815 (1st Dep't 1922); Lamont v. Travelers Ins. Co., 281 N. Y. $362,370,24$ N. E. 2d. 81 (1939) (dictum), reversing 254 App. Div. 5Ir, 5 N. Y. S. 2d 295 (Ist Dep't I938); Fields v. Predionica I Tkanica A. D., 265 App. Div. I32, 37 N. Y. S. 2d 874, 883 (Ist Dep't I942) (dictum), reversing 35 N. Y. S. 2d 408 (Sup. Ct. 1942); United States of Mexico v. Schmuck, 293 N. Y. 264, 56 N. E. 2d 577 (1944). But see Hannes v. Kingdom of Roumania Monopolies Institute, 260 App. Div. 189, 20 N. Y. S. $2 d 825$ (Ist Dep't 1940). See also, Harvard Draft Convention, art. 8(c), 26 AM. J. INr'L L. Supp. 451, 456 (1932). In Frazier v. Hanover Bank, 1x9 N. Y. S. 2d 319 (Sup. Ct. 1953), aff'd, 281 App. Div. 861, 119 N. Y. S. 2d 918 (Ist Dep't 1953), the court refused to read a waiver of immunity in a provision of bonds issued in New York by the Peruvian Government providing that the law of New York applied to the construction of the bonds.

Nevertheless, waivers of immunity are not unknown in loans made by Amcrican bankers to forcign governments. For example, the loan agreement of Feb. 8, 1945, between The Chase National Bank of the City of New York and the Kingdom of the Netherlands, provides, in part, in \$4, para. I:

"The Government hereby irrevocably waives all claim or right to sovereign or other immunity in relation to the enforcement in any jurisdiction of any or all of its obligations and of its warranties and representations under this Agreement, including enforcement of the mortgage of the Security hereunder or in relation to any claims for breach of warranty or misrepresentation by the Government based on or arising out of this Agreement, and irrevocably agrees that the rights of the Manager or of the Banks or of any of them with respect to repayment of all advances under the loan, with interest and commitment charges thereon, and in and to the Security and with respect to all of its other obligations hereunder and of its warrantics and representations may, to the extent decmed necessary or desirable by them or any of them, be finally adjudged or determined in any court or courts of the State of New York or of the United States of America having jurisdiction in the State of New York, or in any other court having jurisdiction, even though such adjudication finally determines the rights or claims of the Government; and the Government hercby submits generally and unconditionally to the jurisdiction of said courts and of any of them in respect of such advances under the loan, with interest and commitment charge thercon, the enforcement of the mortgage of such Security, the enforcement and execution of any judgment against it, and all of its other obligations hereunder."

${ }^{37}$ Duff Development Co. v. Government of Kalantan, [1924] A. C. 797; and Kahan v. Pakistan Federation, $[195 \mathrm{I}] 2 \mathrm{~K}$. B. 1003.

${ }^{33} \mathrm{~A}$ typical provision, in this respect, reads as follows:

"All payments of principal of and interest on the Bonds shall be exempt from, and shall be paid by the [name of debtor] without deduction on account of, any and all taxes and duties of whatsocver nature, including estate and succession duties, now or hereafter imposed by or within the [name of debtor] or any subdivision or taxing authority thereof, except to the extent of any liability imposed by law when a Bond is beneficially owned by a person residing in or ordinarily a resident of [name of debtor]."

See, e.g., Union of South Africa, External Loan Bonds of December 1, 1955, issued in Ncw York.

${ }^{30} \mathrm{~A}$ typical provision (as translated) provides that the borrower undertakes to assurc the transfer of funds necessary to service the loan: ". . . at any time, without any restrictions and under all circum. 


\section{IV}

\section{Loans by Public Lenders to Private Borrowers}

Normally, governments do not lend directly to private foreign borrowers. The usual transactions in this category are loans by public lending institutions. But it would seem that in either case the loans would be governed by municipal law and that these loans should, therefore, not differ materially from loans by private lenders to private borrowers in respect of choice of law by stipulation. Nevertheless, stipulations of applicable law seem to be less consistently employed in loans of this type.

For instance, the Export-Import Bank of Washington, a government corporation organized under United States law and wholly owned by the United States Government, ${ }^{40}$ does not customarily resort to stipulations of applicable law in its loan agreements with private borrowers. Presumably, these agreements are governed either by American law or by the law of the borrower's country or perhaps, in some respects, by each.

A different practice is adopted by the High Authority of the European Coal and Steel Community in its loans to enterprises within the Community. The European Coal and Steel Community is an international organization created by international agreement and composed of sovereign governments. ${ }^{41}$ Its loans to private borrowers, like those of the Export-Import Bank, are presumably subject to the ordinary rules of the conflict-of-laws. Unlike the Export-Import Bank, however, its consistent practice in loans to private borrowers is to make use of stipulations of applicable law. Its standard form of loan contract provides, in article XVII $:^{42}$

The parties agree that this contract shall be governed by the law of [name of member country in which borrowing enterprise is located]. (as translated)

The inclusion of this stipulation is not necessarily to be attributed to a desire to avoid conflicts of law. The leading motivation may well have been a desire on the part of the High Authority to conform to normal financial patterns in its member countries and to avoid having all its loan contracts governed by the laws of one

stances, without any discrimination as to nationality or domicile of the holder and without asking presentation of an affidavit or the fulfilment of any other formality." See, e.g., Union of South Africa $4 \%$ Bonds of 1952, Prospectus, cl. 6(c). The practical effectiveness of such a provision, like that of other governmental covenants, depends largely upon the willingness of the government to stand by its undertaking. Thus, a transfer clause, similar to that quoted above, in bonds issued in I939 in Switzerland by the French government did not prevent that government from requiring after the war from the holders affidavits as to their residence or citizenship, despite Swiss protest against this practice. Sec Frcy, Capital Export from Switzerland, in International Bar Association, 3d Conference Report 237 (1950). The dispute was, however, amicably settled in $195 \mathrm{I}$.

${ }^{10} 59$ STAт. 526 (1945), as amended, 12 U. S. C. $\$ 635$ (1952).

1 Treaty of July 18, 1952 between Belgium, France, Germany, Italy, Luxembourg, and the Netherlands.

12 This Article (as translated) reads further:

"Those questions which shall not be settled by an express provision of this contract, or by such law, shall be solved by the Court of Justice which shall take into account the general principles of law applicable in the six members of the Community. However, controversies or conflict of laws issues relating to the notes executed pursuant to this contract shall be settled pursuant to the Geneva Convention of June 7, 1930." 
particular member country, Luxembourg. Moreover, loans by the High Authority to private borrowers are normally secured by mortgages, and the law of the borower's country has the additional advantage of being that of the situs of the mortgaged property. ${ }^{43}$

Another public international organization, the International Bank for Reconstruction and Development, likewise makes loans to private borrowers. However, it is the International Bank's practice, in accordance with a provision of its charter, ${ }^{44}$ to require a guarantee of each of its loans by the government of the country in which the project being financed is located, unless that government is itself the borrower. Therefore, the International Bank's loans to private borrowers differ from those made by the Export-Import Bank and the European Coal and Steel Community and are best discussed in the next category of loans.

\section{$\mathrm{V}$ \\ Loans by Public Lenders to Foreign Governments and InTERNATtonal Organizations}

This category takes us out of the field of the conflict of laws and into that of public international law. Loan agreements between governments and guarantee agreements between governments, being international agreements, are governed by the rules of law that apply, by custom and international convention, to the relations between sovereign states. ${ }^{45}$ Under the law of treaties, a party to an international agreement cannot invoke its own domestic law to escape its international obligations. ${ }^{46}$ For this reason, international agreements normally do not give rise to problems of the conflict of laws, and it is, therefore, to be expected that agreements falling into this category will not normally contain stipulations of applicable law.

In this field, the practice of lenders and borrowers is fully in accordance with that expectation. Intergovernmental loans consistently contain no stipulations of applicable law.

${ }^{13}$ Blondeel and Vander Eycken, Les emprunts de la Communauté Européenne du Charbon ct de l'Acict, in ig La Revue de la Banque 249, 274 (Belgium I955).

"Art. III, $\S_{4}(\mathrm{i}), 2$ U. N. Treaty Series [hereinafter U. N. T. S.] 134, 144 (1947).

${ }^{25}$ As to loans, see, e.g., Loan Agreement between Belgium and France, Sept. 7, 1949, 123 U. N. T. S. 15 (1952); Loan Agreement between Belgium and the United Kingdom, Sept. 7, 1949, ro6 U. N. T. S. 6I (I95I); Agreement between the United Kingdom, Australia, India, Pakistan, and Ceylon, on the one hand, and, on the other, Burma respecting a loan of $£ 6$ million to be made by the five Commonwealth governments to Burma, June 28, 1950, 87 U. N. T. S. 153 (195I); and Financial Agreement between the United Kingdom and France, March 27, 1945, 98 U. N. T. S. 227 (195I), with a Supplementary Agreement of April 29, 1946, 98 U. N. T. S. 123 (195I).

As to guarantees, see, e.g., the Greek loans of 1833 and 1893 guaranteed by England, France, and Russia; the Egyptian loan of 1885 guaranteed by Austria, England, France, Germany, Italy, and Russia; and the Austrian Government Guaranteed loan of 1923, guaranteed by a number of powers and issued under the auspices of the League of Nations. See also, Wells, Guarantecs in International Economic Law, 4 INT'L Comp. L. Q. 426 (1955); Fawcett, The Legal Character of International Agreements,-30. BRTT. Y. B. INT'L L. 381 (1953); and I BoRchard, op. cit. supra note 22, at 65.

${ }^{10}$ See 5 G. H. Hackworth, Digest of Internationat. Law i85 (I943); 2 C. C. Hyde, Internatonal LaW 1454 et seq. (2d ed. I947); I L. F. L. Oppenheim, International Law 829 et seq. (6th ed., Lauterpacht, x947). 
The same is true of monetary agreements, such as payments agreements, clearing agreements, and the like. These are also normally entered into between governments and are, therefore, governed by public international law. They, thus, afford no occasion for avoidance of the conflict of laws and do not normally contain any provision on the subject. ${ }^{47}$

When loans to governments are made not by governments themselves, but by public lending institutions, the determination of the applicable law is more difficult. For instance, the Export-Import Bank of Washington, in its lending operations, sometimes acts as agent of the Government. ${ }^{48}$ Since, in these loans, the United States is the contracting party, the contracts are international agreements governed by public international law. When, on the other hand, the Export-Import Bank lends for its own account to foreign governments, it might be argued that the Bank does not enjoy international personality and that its contracts are, therefore, not governed by public international law. ${ }^{49}$ Notwithstanding this possible distinction, the Export-Import Bank's loan documents do not include stipulations of applicable law in either class of case.

The International Bank for Reconstruction and Development is an international organization whose members are governments. It was created by international agreement according it full juridical personality in the territories of members and giving it wide international responsibilities in the economic field. As such, it must be considered to possess international personality and to be a subject of international law. ${ }^{50}$ As mentioned above, its loans are made either to governments or with the guarantee of governments. Since the lender and the borrower (or, in the case of guarantee agreements, the lender and the guarantor) are both subjects of international law, the relationship should be governed by public international law. ${ }^{51}$ The Bank's

\footnotetext{
${ }^{47}$ For general discussion of agreements of this kind, see, e.g., Hug, Le droit des paiements internafionaux, 79 RECuEIL DES CouRs 515 (France 195Y).

${ }^{18}$ Such was the case in respect to the Marshall Plan loans and the loan made in 1954 by the United States Government to the High Authority of the European Coal and Steel Community.

${ }^{10}$ The issue is raised in two articles by Mr. Mann. See Mann, The Assignability of Treaty Rights, 30 BRIT. Y. B. Int'L L, 475 (1953); and Mann, The Latv Governing State Contracts, 21 id. at II (1944). The following statement appears in 5 United Natrons, Repertory of Practice 295 (1955) with respect to the registration of treaties and international agreements under art. I02 of the United Nations Charter: "Agreements between States and certain governmental or semigovernmental agencies, such as the Institute of Inter-American Affairs and the Export-Import Bank, were also considered [by the Secretariat] as not subject to registration after consultation with the Governments concerned."

Eo That "international personality" is not an attribute of states alone was recognized by the International Court of Justice in the Reparations for Injuries case in which the Court held that the United Nations possesses international personality. [1949] I. C. J. Rep. I74, 178, I79. The international personality of the Bank was explicitly recognized by Switzerland in art. I of the Agreement of June 29, r95I between the Swiss Federal Council and the Bank. See also Wells, supra note 45; and Adam, Les Accords de Prêt de la Banque Internationale pour la Reconstruction et le Développement, in 55 Revue Génerale de Droit International Public 4r, 57 (France 195 r).

51 The Regulations adopted by the General Assembly of the United Nations to implement the - Charter provision (art. 102) for the registration of treaties and international agreements include among "international agreements" agreements between states and specialized agencies such as the Bank. Loan and Guarantee Agreements between the Bank and member governments are registered or filed by the
} 
loan documents are consistent with this conclusion. They make clear the intention of the parties that the terms and conditions of the contract shall not be frustrated by conflicting domestic law. The Bank's Loan Regulations, which are incorporated by reference into the Bank's loan agreements with member governments, contain the following provision: $:^{52}$

The rights and obligations of the Bank and the Borrower under the Loan Agreement and the Bonds shall be valid and enforceable in accordance with their terms notwithstanding the law of any state, or political subdivision thereof, to the contrary....

Two other international organizations, the International Monetary Fund and the European Payments Union, also engage on a large scale in financial transactions with governments. Their transactions take the form of exchange transactions rather than of loans, and the essential elements of the obligations imposed by the transactions are defined by international agreement and by regulations issued thereunder. ${ }^{53}$ There would, therefore, normally be no need for any stipulation of applicable law in regard to these transactions, and neither institution has made a practice of using such provisions.

Loans from governments to public international organizations should, on the analogy of loans from public international organizations to governments, likewise be governed by public international law, and stipulations of applicable domestic law are not to be expected in these transactions. Examples are the loan from the United States Government to the United Nations to finance the construction of the head. quarters building ${ }^{54}$ and the loan from the United States Government, acting through the Export-Import Bank, to the High Authority of the European Coal and Steel Community. ${ }^{55}$ Neither contains any stipulation of applicable domestic law.

Bank with the Secretariat of the United Nations as international agreements and are accepted as such by the Secretariat. See note 50 supra.

${ }^{62}$ See Loan Regulations of the Bank No. 3, dated Feb. 15, 1955, art. VII, \$7.0r. A similar provision is included in Loan Regulations No. 4, dated Feb. 15, 1955, covering loans made, with governmental guarantee, to borrowers other than governments.

${ }^{53}$ The Article of Agreement of the International Monetary Fund are found in 2 U. N. T. S. 39 (1947). The Articles of Agreement of the European Payments Union are found in 77 CLuNET 996 (France I950).

5f Loan Agreement of March 23, 1948, 19 U. N. T. S. 43 (1948).

${ }^{55}$ Official Gazette of the Community, May 7, 1954, at 325. For a different view, sec however, Blondecl and Vander Eycken, supra note 43, at 273-74. In pointing out that "American" law was probably intended, these writers emphasize that: "The United States are the place of contracting, the place where the funds were raised and must be repaid; all other factors such as the language [of the agreement], [its] legal terminology, the currency involved, contribute to point out that it is really the American law which is applicable." Id. at 274. But see art. 6 of the Charter of the European Coal and Stecl Community, which provides:

"The Community shall have juridical personality.

"In its international relationships, the Community shall enjoy the juridical capacity necessary to the exercise of its functions and the attainment of its ends.

"In each of the member States, the Community shall enjoy the most extensive juridical capacity which is recognized for legal persons of the nationality of the country in question. Specifically, it may acquire and transfer real and personal property, and may sue and be sued in its own name.

"The Community shall be represented by its institutions, each one of them acting within the framework of its own powers and responsibilities." 46 Am. J. INr'L L. Iog-10 (Supp. 1952). 
Yet, the fact that a loan is governed by public international law and the law of treaties does not necessarily eliminate all conflicts problems. Unlike international agreements dealing with such traditional subjects as the termination of hostilities, the fixing of boundaries, and the like, intergovernmental loans have to do with the subject matter of private commercial contracts. They, therefore, tend to use words such as the English "tender," "trust," and "delivery" and the French "payable," which, through years of use in commercial practice and in codes, statutes, and court decisions, have acquired technical meanings. It would, therefore, seem quite within the bounds of possibility that the parties to an intergovernmental loan agreement, desiring to avoid disputes as to the meaning of technical terms, might stipulate that the agreement should be interpreted in accordance with the law of one party or the other. No example has been found of such a provision in an intergovernmental agreement. The early loan contracts of the International Bank for Reconstruction and Development, however, contained a provision of this character. ${ }^{56}$ The purpose of this provision was occasionally misunderstood by borrowers, and the Bank now does not normally include such a provision in loan documents. The Bank was influenced by the consideration, among others, that since these agreements are entered into in the United States and drafted in English, usage in the United States and other English-speaking countries would, in any case, be looked to as a guide in their interpretation. ${ }^{5 T}$

Problems may arise that go beyond matters of interpretation. For example, a pledge, mortgage, or other security arrangement may be given to secure a loan provided for by international agreement, and the property charged as security may be situated in territory under the jurisdiction of a government which is not a party to the agreement. If it is desired that the security arrangement should be enforceable by ordinary domestic procedures, it will presumably be necessary to frame the contract so as to permit the security arrangement and its enforcement to be governed by the law of the situs. For example, under a loan from the International Bank for Reconstruction and Development to Iraq, ${ }^{58}$ the obligations of the borrower were secured by an assignment of oil royalties due Iraq from a British company. And under the loan from the United States of America to the High

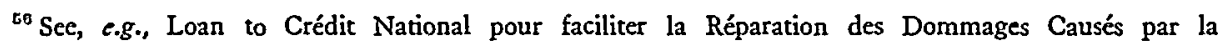
Guerre, guaranteed by the Republic of France, May 9, 1947, art. IX, \$2: "The provisions of this Agreement and of the Bonds and of the Guarantee Agreement shall be interpreted in accordance with the law of the State of New York, United States, as in effect at the date of this Agreement." The Guarantee Agreement and the Loan Agreement annexed thereto were registered with the Secretariat of the United Nations on Jan. 13, 1953, under No. 2014.

${ }^{57}$ See, e.g., 5 HACkWORTH, op. cit. supra note 46, at 222 et seq.; 2 HXDE, op. cit. supra note 46, at 1471 et seq.; I Rousseau, Principes Généraux du Droit International Public 708 et seq. (i944); Delaume, De l'Application et de l'Interprétation des Traités par les Tribunatux Internes dans les Relations Franco-Américaines, 8o CLUNeT 584, 622 et seq. (France I953) (with an English translation by the editor).

${ }^{28}$ This loan was registered with the Secretary General of the United Nations on Jan. 13, 1953, under No. 2038 . 
Authority of the European Coal and Steel Community, the borrower's obligations are secured by a pledge of obligations owed by private companies to the High Authority under an indenture of which the trustee is the Bank for International Settlements, a corporation organized under a special charter granted by Swiss law, pursuant to an international convention. ${ }^{59}$ Although the documents relating to these two loans contain no affirmative stipulation that the domestic law of a particular country shall govern the security arrangements, they equally do not contain any provision which would expressly preclude application of the appropriate domestic law as determined by ordinary rules of conflicts.

The problem of determining applicable law may arise in yet another way. The International Bank, whose loans often involve repayment in several currencies and in several countries, incorporates in its loan contracts a special provision on exchange restrictions reading as follows: ${ }^{60}$

Exchange Restrictions. Any payment required under the Loan Agreement to be made to the Bank in the currency of any country shall be made in such manner, and in currency acquired in such manner, as shall be permitted under the laws of such country for the purpose of making such payment and effecting the deposit of such currency to the account of the Bank with a depository of the Bank in such country.

This provision suggests that even in loans which are governed by public international law, it may, on occasion, be desirable for the parties to stipulate that any performance to be rendered in a country not a party to the loan contract shall be rendered in accordance with the laws of that country. However, no example has been found of such a stipulation in intergovernmental loans.

Finally, rights under an international agreement may be assigned to private parties. For instance, the International Bank sometimes transfers to private investing institutions all or part of its rights to receive principal and interest due on loans made by it. Such transfers may be made by simple assignment or by transfer, by endorsement or otherwise, of bonds or notes received by the lender from the borrower under the loan contract. In fact, the International Bank has, during the past year, sold and agreed to sell obligations of its borrowers payable in various currencies in an aggregate principal amount equivalent to about \$roo million. The loan contracts of the International Bank do not contain provisions purporting to specify the law applicable to the rights of the holders of such obligations after their transfer. The contracts, thus, leave open the provocative question, posed by an eminent writer, of determining the law applicable to treaty rights assigned to private parties. ${ }^{61}$

\footnotetext{
${ }^{50}$ See 5 Maniey Hudson, International Legislation 307 (1936).

${ }^{60}$ Loan Regulations Nos. 3 and 4 , art. III, $\$ 3.06$ (Feb. 15, 1955).

${ }^{61}$ See Mann, supra note 49.
} 


\section{ConcLusion}

In the field of private international lending, avoidance of conflicts does not pose serious problems for lenders and borrowers. The established practice of stipulating applicable law appears adequate to avoid most conflicts, even in the relatively rare cases where generally accepted rules of the conflict of laws furnish no clear guide. However, it is still too early to come to any definite conclusion as to the attitude which national courts will take towards article VIII, section 2(b), of the Fund Agreement in the field of exchange contracts.

In the field of loans and monetary agreements between governments or between governments and public international organizations enjoying international personality, avoidance of conflicts is at present of little concern to the parties. However, as governments and public international organizations engage more and more in transactions resembling private financial transactions, problems of conflicts of law, or at least analogous problems, are increasingly likely to arise, and, as Sir John Fisher Williams prophesied some thirty years ago, ${ }^{62}$ usage will correspondingly tend to be influenced by the norms of private financial practice.

In the field of loans between persons subject to different legal orders, i.e., between private persons on the one side and governments or international organizations on the other, there is no unanimity of view as to the applicable law; and except in a few countries, the practice of avoiding conflicts by stipulation has not developed to the point of furnishing a solution. The confusion created in this field by the gold clause cases of the thirties led the Financial Committee of the League of Nations to suggest as a possible solution an international convention to establish a code of substantive rules applicable to loans from private lenders to governments. ${ }^{63}$

It is to be doubted whether a solution will soon be found along the lines suggested by the Financial Committee of the League. The difficulty of reaching multilateral agreement among parties with diverse interests on substantive issues involving important questions of public policy is apparent; and the fact that nothing has come of the Committee's suggestion fifteen years after it was originally made is sympto-

02 “. . . quand on a mis de coté des questions, soit d'indépendance, soit de souveraineté, quand on traite les affaires on hommes d'affaires, quand les Etats élaborent les détails de leurs rapports financiers, nous constatons une tendance très apparente, pour ne pas dire une nécessité, d'assimiler leurs opérations à celles des particuliers et des personnes morales dans le champ du droit privé. C'est ainsi que les rapports financiers internationaux, plus peut-être, que toute autre catégorie d'opérations internationales, se classent par catégories juridiques et qu'on peut les régler par des doctrines juridiques bien connues, ou tout au moins les y adapter.

“. . Mais aussitôt que les Etats se recontrent en hommes d'affaires, aussitôt qu'il s'agit d'elaborer les détails de leurs rapports financiers, les juristes, les practiciens, les experts qui s'en chargent vont forcement suivre les routes qui leur sont connues en droit privé, et les obligations financières des gouvernements vont s'exprimer sous des formes qui ressemblent merveilleusement aux obligations, que contractent par exemple les grandes societes anonymes qui exploitent des services d'utilite publique." Williams, L'Entr'aide Financière Internationale, 5 RecueIL DES Cours 8, I43 (France 1924).

${ }^{63}$ L. N. REPORT $\$ 83$. The International Institute for the Unification of Private Law, at Rome, has prepared a Preliminary Draft Uniform Rules Applicable to International Loans. 20 INstrituTE Papers: International Loans (Doc. 5a(I) (I947)). 
matic. If, contrary to the expectations of the writers, a code of substantive rules could be adopted, the conflicts problems would be solved along with the substantive problems "by removing the subject from the field of municipal law into that of international law."64 But even this would not be a complete solution, for in the minds of most lenders, both these problems are overshadowed by the problem of enforcement. Lenders would continue to feel that, in the absence of changes in their own national law regarding sovereign immunity and in the absence of an international tribunal having jurisdiction, their only real protection is the good faith and credit of the borrowing government.

et L. N. REPORT $\$ 83$. 